\title{
Empirical Analysis on Monetary Policy Efficiency in China
}

\author{
Jieqiu Wan \\ School of Business \\ Soochow University \\ Suzhou, China \\ WJQ@suda.edu.cn
}

\author{
Gui Cheng \\ School of Finance \\ Lanzhou University of Finance and Economics \\ Lanzhou, China \\ Chenggui80@163.com
}

\author{
Tao Xu \\ School of Business, \\ Soochow University \\ Suzhou, China \\ tylerxu@sina.com
}

\begin{abstract}
As an important indicator to test the effectiveness of monetary policy, monetary policy efficiency has long been discussed. In this paper, we adopt the stochastic frontier analysis (SFA) based on translog function to measure the Chinese monetary policy efficiency from 1998 to 2011. Our empirical results indicate that economic growth and price stability have the same weights in the Chinese monetary policy function. Money aggregate (M2) has a larger impact on the monetary policy targets than interest rate does. Generally speaking, Chinese monetary policy efficiency is not so high and needs to be improved. To enhance monetary policy efficiency, China should reform its monetary policy framework by introducing the flexible targets into the monetary policy framework, further the interest rate reform and continue the reform on the Renminbi exchange rate regime.
\end{abstract} $S F A$

Keywords-Monetary policy efficiency; Monetary policy targets;

\section{INTRODUCTION}

As one of the major means of macroeconomic policy, monetary policy has played a crucial role for maintaining healthy economic growth. With the evolution of financial innovation, economic globalization and integration, it becomes harder and harder for the Chinese central bank (People's Bank of China) to conduct monetary policy and the monetary policy efficiency is generally not so ideal. In the recent years, with the interchange of inflation and deflation, People's Bank of China becomes impotent in monetary policy conduct. For example, since the late 2008, the Chinese economy began to recess for the negative impact of the subprime crisis. To maintain economic growth, encourage domestic demand and adjust industrial structure, People's Bank of China has reduced interest rate and deposit reserve requirement ratio for four times consecutively to encourage the commercial banks to increase loans. The monetary policy has converted from the original contractionary state to a moderately easy state. With the stimulation of the moderately easy monetary policy, the economy has improved gradually. But simultaneously, there have been some signs of excessive liquidity and increasing inflationary pressure. So, in the late 2010, China has shifted the monetary policy from moderately easy policy to stable policy. In 2011, People's Bank of China has increased the loan rates for three times and the legal deposit reserve requirement ratio for six times. Within less than three years, the People's Bank of China has changed the tone of monetary policy many times in hope to stabilize growth and price, but it has only led to instable inflationary expectation and fluctuating output.

Presently, the European Sovereign Crisis is still at its climax, the international financial market is fluctuating greatly, and the global economy is on the verge of plummeting. With this complicated external economic situation and sharp domestic social and economic conflicts, there are more and more difficulties in the economy and the financial risks have been accumulating too. All these have composed a huge challenge for the monetary policy conduct. Hence, it is of great practical importance to study the Chinese monetary policy efficiency and improve the mechanism of monetary policy conduct and efficiency. In this paper, we have adopted empirical method to analyze the overall efficiency of the Chinese monetary policy and provide some suggestions.

\section{LITERATURE REVIEW}

Monetary policy efficiency is always the hot issue in the academic cycle. The Chinese researchers have done many fruitful studies in this field. There are two strands of studies. The first is the formative studies on monetary policy efficiency. Zhang, Jie (1997) finds that it becomes harder and harder for China to conduct macroeconomic policies since 1996. There are two major reasons: one is the costly defining of financial property rights, the other is the increase in financial control cost caused by the trap of public financial property rights. Ba, Shusong (2000) has analyzed the financial environment, the trend and the determinants of monetary policy and he finds that the determinants of monetary policy include financial structure, the nonperforming assets, the dual regional financial structure and the dual structure of financial markets. Besides, Yu, Hui (2007) has studied the monetary policy environment based on the evolution of the Chinese financial structure, the 
disequilibrium financial market, savings-investment structure and the degree of economic openness. The results indicate with the significant financial structure, the slow adjustment of monetary policy, the disequilibrium of financial markets, the hardness of savings-investment conversion, the existent interest rate regulation and the increase in economic openness have become significant environmental determinants for the low monetary policy efficiency in China. The second strand of literature is the empirical analysis on monetary policy. Wan, Jieqiu \& Xu, Tao (2001)'s empirical analysis indicates that with the economic growth and the independence of the economic agents' decision-making process, there is stronger and stronger endogeneity in the Chinese money supply, which has added to the difficulty in monetary policy conduct and has caused the asymmetric feature in the effects of monetary policy during inflation and deflation periods. Hence, it is hard to achieve the expected objectives simply through easy or contractionary monetary policy. Chen, Liping (2006) has constructed a monetary policy model with time lag and shocks to the monetary policy transmission, and analyzed the monetary policy efficiency with a money stock intermediate target. His results indicate that because there is a time lag for monetary policy to influence inflation, output and money stock and because these macroeconomic variables cannot be observed simultaneously, the inclusion of monetary policy intermediate targets can provide a signal for the present shocks and extra information, which can make central banks and the public adjust their expectation so as to improve monetary policy efficiency. He has also found that if the monetary policy transmission mechanism does not work, the monetary policy stock intermediate targets cannot respond to the economic shocks. If so, the monetary policy efficiency cannot be improved and the central bank reputation will even be harmed.

\section{EMPIRICAL ANALYSIS}

\section{A. Methodology, Model Specification and Data Description}

1) Methodology and Model Specification: Data Envelopment Analysis (DEA) and Stochastic Frontier Analysis (SFA) have frequently been used in economic and financial study. DEA can measure efficiency through linear programming. As a nonparametric method, DEA does not need to specify the production function, and it only needs input and output data. Because DEA assumes all the deviation from the efficient frontier is caused by specific inefficient factors, it hasn't considered the impacts of stochastic shocks. SFA is a parametric method based on tradition regression. The core concept of SFA is to construct the stochastic production frontier with production function and stochastic shocks, so its results depend on the ex ante specification of the production function and the probability distribution of stochastic shocks. Since monetary policy conduct may be affected by stochastic factors, we adopt SFA to measure the monetary policy efficiency in China.

Stochastic Frontier Analysis was put forward by Aigner, Lovell and Schmidt (1977) and Meeusen and Van den broeck(1977) respectively. They have defined production frontier as "the maximum output level with given inputs and their combination". SFA model with time series data usually includes the following equations:

$$
\begin{aligned}
& \ln Y_{t}=\ln f\left(X_{t}, \beta\right)+v_{t}-u_{t} \\
& \chi=\frac{\sigma_{u}^{2}}{\sigma^{2}}, \sigma^{2}=\sigma_{u}^{2}+\sigma_{v}^{2} \\
& \mathrm{TE}_{t}=E\left\{\exp \left(-u_{t}\right) / v_{t}\right\}
\end{aligned}
$$

Where $Y_{t}$ is real output, $X_{t}$ is a vector of inputs, $f(\cdot)$ is production function, $v_{t}$ is stochastic error term following standard normal distribution. $u_{t}$ is the technical inefficient term, which represents the impacts of technical inefficiency on output. Normally, $u_{t}$ is a non-negative random variable. In this paper, we assume it with a semi-normal distribution. $\sigma_{v}$ and $\sigma_{u}$ are the standard deviations of $v_{t}$ and $u_{t}$ respectively. $\mathrm{TE}_{t}$ is the measurement of efficiency, and $\mathrm{TE}_{t} \in[0,1]$.

In (1), $\chi \in[0,1]$. If $\chi \rightarrow 0$, there does not exist the inefficiency term. If $\chi \rightarrow 1$, the deviation from the efficient frontier is caused mainly by the inefficiency term.

The first step to measure monetary policy efficiency with SFA is to specify the production function. The frequently used function includes Cobb-Douglass production function (C-D function) and translog production function (Tranlog function). Translog function has many virtues as a variable elastic production function with easiness in estimation and high compatibility. It can reflect the mutual influence between all the input factors and the differences in their role in technical progress. For the difficulty in determining the type of the production function and the complicated mutual influence of the monetary policy instruments, we have assumed our production function as a translog-form function. The SFA model based on translog function can be written as follows:

$\ln Y_{t}=\beta_{0}+\sum_{i=1}^{n} \beta_{i} \ln x_{i}+\sum_{i=1}^{n} \sum_{j=1}^{n} \beta_{n m} \ln x_{n} \ln x_{m}+v_{t}-u_{t}$

Besides, we should select some variables to estimate the above translog function. China has set her monetary policy target as "stabilizing the value of currency so as to quicken the economic growth." Hence, there are three targets altogether: maintaining price stability, maintaining exchange rate stability and quickening economic growth. Since the aim of maintaining exchange rate stability is to realize price stability and to quicken economic growth ${ }^{1}$, and in practice the monetary policy has been conducted more for price stability and economic growth, we have omitted the exchange rate variable, and set the monetary policy targets as maintaining price stability and quickening economic growth. Besides, there can only be one

\footnotetext{
${ }^{1}$ According to money and banking theory, exchange rate is usually
} considered as an intermediate variable not the final target. 
output variable for monetary policy, we have to decrease the dimension of the economic growth target and the price stability target. The principal component method with unequal weights has been adopted to decrease the dimension to achieve an aggregative monetary target variable $Y_{t}$. Moreover, according to the status quo of the Chinese monetary policy, money aggregate $\left(\mathrm{M}_{2}\right)$ and interest rate have been adopted as the input variables. Hence, the translog function of the SFA for the Chinese monetary policy can be specified as follows:

$$
\begin{aligned}
\ln Y_{t}= & \beta_{0}+\beta_{1} \ln M_{2, t}+\beta_{2} \ln \text { Rate }_{t}+\beta_{3}\left(\ln \text { Rate }_{t}\right)^{2} \\
& +\beta_{4}\left(\ln M_{2, t}\right)^{2}+\beta_{5} \ln \text { Rate }_{t} \ln M_{2, t}+v_{t}-u_{t}
\end{aligned}
$$

- 2) Data Description:We use the growth rate of nominal quarterly GDP as the economic growth variable and the quarterly CPI change as the inflation variable. The interest rate is calculated with the weighted interbank rate of the last seven days of each quarter, while the money supply is the growth rate of $\mathrm{M}_{2}$ at the end of each quarter. Since the People's Bank of China claimed to abandon the loan quota control for the state-owned commercial banks and adopt asset liability ratio regulation and risk regulation in January 1, 1998, China began to shift direct policy conduct to indirect conduct. Hence, our sample period lasts from the first quarter of 1998 to the fourth quarter of 2010, with totally 52 observations. All the data are taken from China Economic Information Network. SPSS11.5 and Stata10.0 have been used for our empirical analysis.

\section{B. Empirical Analysis}

\section{1) Principal component analysis}

\begin{tabular}{|c|c|c|c|c|c|c|c|c|c|}
\hline \multicolumn{7}{|c|}{ Varianoe explamed } & \multicolumn{3}{|c|}{ Conporext Mathix } \\
\hline \multirow[b]{2}{*}{ Conqonent } & \multicolumn{3}{|c|}{ Intial Fizeng Wahe } & \multicolumn{3}{|c|}{ Extracted square sum loading } & & & \\
\hline & sum & $\begin{array}{l}\% \text { of } \\
\text { variare }\end{array}$ & $\begin{array}{l}\text { Curvulative } \\
\text { perentage }\end{array}$ & sum & $\begin{array}{l}\% \text { of } \\
\text { variare }\end{array}$ & $\begin{array}{l}\text { Curvulative } \\
\text { percertage }\end{array}$ & & & \\
\hline 1 & 1893 & 94.656 & 94.656 & 1893 & 94.656 & 94.656 & \multirow{2}{*}{ component 1} & GDP & 0973 \\
\hline 2 & 0.107 & 5344 & 100000 & & & & & $\mathrm{CPI}$ & 0973 \\
\hline & & GDP & : oefficient & 0514 & CPI so: & re cofficient & 514 & & \\
\hline
\end{tabular}

TABLE I. PRINCIPAL COMPONENT ANALYSIS RESULTS

Table I has reported the principal component analysis results for GDP and CPI. The results indicate that the cumulative contribution of component 1, i.e. the monetary policy target aggregative variable (Y) has reached $94.856 \%$, much higher than the normally accepted threshold $80 \%$, and this aggregative variable has included $97.3 \%$ information from GDP and CPI respectively. According to the score coefficients of GDP and CPI, we can develop the expression of the Chinese monetary policy target aggregative variable: $Y=0.514 \times(C P I+G D P)$.

2) Measurement of monetary policy efficiency based on the SFA model

Table II has reported the maximum likelihood estimator of the translog function. The null hypothesis of $\sigma_{u}=0$ can be rejected significantly with $\chi=0.99999$, which indicates that there exists the inefficiency term and it can pass the maximum likelihood test. The coefficients of all the variables can pass the $\mathrm{Z}$ test and their notes are the same as our expectation. Much strikingly, the note of $\mathrm{M}_{2}$ 's coefficient is positive, while that of the square of $\mathrm{M}_{2}$ is negative. This indicates that given interest rate constant, money supply has a reverse $U$ shaped impact on the monetary policy target variables. It indicates the money supply increase can realize the monetary policy targets to some degree, but with the continuous money supply increase, the monetary policy efficiency will decrease. In fact, the excessive money supply increase will induce inflation, do harm to economic growth and decrease the overall national welfare. The coefficient of the square of interest rate has a negative sign, which indicates the interest rate also has a reverse U-shaped impact on the monetary policy target. When the interest rate is very low or even negative, interest rate increase can encourage savings and promote investment and economic recovery. With the continuous interest rate increase, especially when it has passed a threshold, the interest rate increase will repress investment and decrease the economic growth rate and inflation rate. Besides, the absolute value of the coefficient of money supply $\left(\mathrm{M}_{2}\right)$ is much bigger than that of interest rate, which indicates money supply has a larger impact on the monetary policy target aggregative variable than interest rate does. It has reflected the fact that China has set money supply $\left(\mathrm{M}_{2}\right)$ as the intermediate target of monetary policy. So the translog function of China monetary policy can be written as follows:

$$
\begin{aligned}
\ln Y_{t}= & -9.27+7.98 \ln M_{2, t}-1.94 \ln \text { Rate }_{t}-1.16\left(\ln \text { Rate }_{t}\right)^{2} \\
& -1.49\left(\ln M_{2, t}\right)^{2}+1.6 \ln \text { Rate }_{t} \ln M_{2, t}+v_{t}-u_{t}
\end{aligned}
$$

\begin{tabular}{|c|c|c|c|c|}
\hline $\begin{array}{c}\text { Variable } \\
\text { Name }\end{array}$ & Parameter & $\begin{array}{c}\text { Standard } \\
\text { Error }\end{array}$ & Z-value & $P \succ \mid Z$ \\
\hline Constant & -9.265581 & 0.0016875 & -5490.75 & 0.000 \\
\hline $\ln \mathrm{M} 2$ & 7.979919 & 0.0011748 & 6792.64 & 0.000 \\
\hline InRate & -1.9389 & 0.0004002 & -4844.54 & 0.000 \\
\hline $\begin{array}{c}\text { InRate } \\
\times \\
\text { InRate }\end{array}$ & -1.161137 & 0.0000334 & $-3.5 e^{4}$ & 0.000 \\
\hline $\begin{array}{c}\ln \mathrm{M} 2 \times \\
\ln \mathrm{M} 2\end{array}$ & -1.493087 & 0.0002026 & -7369.79 & 0.000 \\
\hline $\begin{array}{l}\ln \mathrm{M} 2 \times \\
\text { lnRate }\end{array}$ & 1.596813 & 0.0001197 & 13344.83 & 0.000 \\
\hline$\sigma_{v}$ & $1.41 \mathrm{e}^{-8}$ & $3.64 \mathrm{e}^{-6}$ & & \\
\hline$\sigma_{u}$ & 0.7764044 & 0.0761327 & & \\
\hline$\sigma^{2}$ & 0.6028037 & 0.1182195 & & \\
\hline
\end{tabular}

TABLE II. MAXIMUM LIKELIHOOD ESTIMATOR OF SFA MODEL BASED ON TRANSLOG FUNCTION

Likelihood-ratio test of sigma_u=0: chibar2 $(01)=21.26$

Prob $>=$ chibar $2=0.000$ 
With the sample data, we can estimate the monetary policy efficiency in the sample period (See Table 3). The results indicate the average monetary policy efficiency from 1998 to 2010 is only $60 \%$ and the inefficiency is as high as $40 \%$. This has provided the evidence that in this period China's monetary policy has a low efficiency.

TABLE III. SUMMARY STATISTICS OF EFFICIENCY

\begin{tabular}{c|c|c|c|c|c}
\hline variable & observations & mean & $\begin{array}{c}\text { Standard } \\
\text { deviation }\end{array}$ & minimum & maximum \\
\hline Efficiency & 52 & 0.6 & 0.27 & 0.19 & 1 \\
\hline
\end{tabular}

\section{CONCLUSION}

In this paper, we have analyzed the impacts of monetary policy variables such as interest rate and money supply $\left(\mathrm{M}_{2}\right)$ on the monetary policy target aggregative variable with SFA model based on translog function, and estimated the efficiency of China's monetary policy. We have reached the following conclusions:

Firstly, according to our principal component analysis, China should assume the same weights to economic growth and price stability in the monetary policy target aggregative variable. According to monetary economic theories, money is neutral in the long run while not neutral in the short run. So, many western countries have set price stability as the primary target for monetary policy. China is a developing country. Economic growth is still the primary task presently. Hence, in making monetary policy, China should balance price stability and economic growth.

Secondly, money channel is still the main transmission channel for monetary policy in China. Our estimation of SFA model based on the translog function shows that money supply $\left(\mathrm{M}_{2}\right)$ has a greater impact on monetary policy target than interest rate does. In practice, since January 1, 1998, the People's Bank of China has formally abandoned the loan quota regulation and adopted indirect method of monetary policy conduct. Each year, the People's Bank of China will set the growth rate of money supply in the next year and adjust money supply according to the actual economic development. In the recent years, with the furthering of interest rate marketization and the increased sensitivity of the microeconomic agents to interest rate changes, interest rate has become an important monetary policy transmission channel.
Thirdly, China in general has low monetary policy efficiency with a mean value only of $60 \%$. There are many reasons for the low monetary policy efficiency in China, including: the lack of relevance, controllability and measurability of money supply $\left(\mathrm{M}_{2}\right)$ as the intermediary targets of monetary policy (Cheng, Gui, 2013); the imperfect transmission mechanism of interest rate and exchange rate due to the unfinished interest rate and exchange rate reform. Besides, the increasing economic openness and dependence on the global market, the speeding of capital flow have all added to the difficulty of monetary policy conduct. Hence, China should take some measures to enhance monetary policy efficiency. Firstly, China should reform the monetary policy framework by introducing flexible inflation rate target to the existent monetary policy framework in order to enhance the forward-looking feature, pertinence, flexibility of monetary policy. Secondly, China should further the interest rate reform to provide a better monetary policy transmission mechanism. Thirdly, China should further Renminbi exchange rate formation mechanism to enhance the flexibility of Renminbi exchange rate. It can baffle the external shocks to money supply and increase the independence of monetary policy.

\section{REFERENCES:}

[1] Hong, Tao, "Empirical Analysis and Comparison of Fiscal and Monetary Policy Efficiency between China and U.S.A.," Inquiry into Economic Issues, No. 6: 96-100, 2012

[2] Wang, Zhiqiang, "On the Efficiency of Fiscal Policy and Monetary Policy in China - an Empirical Analysis based on Stochastic Frontier Model," Economics Perspectives, No. 8: 45-49, 2010

[3] Wan, Jieqiu \& Xu, Tao, "Money Supply Endogeneity and Monetary Policy Efficiency - Comment on the Effectiveness of China Monetary Policy," Journal of Economic Research, No. 3: 40-50, 2001

[4] Li, Puliang, "Fiscal Expenditure on Agriculture and Agricultural Growth," Local Public Finance Research, No. 1: 49-50, 2012

[5] Ba, Shusong, "Economic Analysis on the Effectiveness of China's Monetary Policy," Economic Science Press, June, 2000

[6] Yu, Hui, On the Effectiveness of China Monetary Policy, China Economic Press, September, 2007

[7] Chen, Liping, "Theoretical Analysis on the Low Monetary Policy Efficiency under the Money Stock Intermediate Target Regime," Financial Research, No. 6: 40-50, 2006

[8] Cheng, Gui, Inflation Target Regime and the Reform on the Framework of China Monetary Policy, [D] Ph.D thesis of Soochow University, June, 2013 